\title{
FACTORS AFFECTING CONSUMER ACCEPTANCE OF DIGITAL FINANCIAL INCLUSION; AN ANECDOTAL EVIDENCE FROM BOGOR CITY, INDONESIA
}

Nevvi Wibella Faculty of Management and Business, Bogor Agricultural University, Indonesia E-mail: nevvi.wibella@gmail.com

Idqan Fahmi Faculty of Economics and Management, Bogor Agricultural University, Indonesia

E-mail: ifahmi@mb.ipb.ac.id

Imam Teguh Saptono Faculty of Management and Business, Bogor Agricultural University, Indonesia E-mail: itsaptono@yahoo.co.id

Submission: $18 / 04 / 2018$

Revision: 25/04/2018 Accept: $17 / 05 / 2018$

\section{ABSTRACT}

Various surveys have been conducted over the past few years indicating financial access in Indonesia is still not good. Digital Financial Inclusion (DFI) which is a digital access to use of formal financial services by underserved populations to solve those problems. The success of the DFI services were not only determined by the service provider, but also by the acceptance of the users. The TAM (Technology Acceptance Model) model offers a powerful and simple explanation of the factors that affect user acceptance of a technology. The main purpose of this research was to understanding consumer acceptance of using DFI which was investigated and measured by several factors through the TAM model ie; perceived usefulness, perceived ease of use, perceived credibility, intention to use, and actual use. The population of this research was conducted in Bogor City because the level of financial inclusion in Bogor City was low but the digital development was quite good. And total sample was 134 respondent. 
INDEPENDENT JOURNAL OF MANAGEMENT \& PRODUCTION (IJM\&P)

http://www.ijmp.jor.br

v. 9, n. 4, October - December 2018

ISSN: 2236-269X

DOI: 10.14807/ijmp.v9i4.824

The PLS SEM analysis showed that perceived usefulness has no significant effect $(p>0.05)$ to intention to use DFI services but perceived ease of use and credibility has significant $(p<0.05)$ and positive effect to consumer interest in using DFI services. Perceived credibility is the most influencing consumer interest in using DFI service because it has the highest coefficient value. The results of this research were expected to improve the development and acceptance of DFI services.

Keywords: DFI services, credibility perceptions, TAM, usability, ease of use

\section{INTRODUCTION}

The survey conducted by the world bank shows that in the 2014 Global Inclusion Database (Figure 1), the percentage of Indonesian population over 15 years who have access to financial services was only $36 \%$, far below Thailand (78\%), Malaysia (81\%), and Singapore (96\%). To solve these problems, Indonesia government has created programs and policies to improve financial access for underserved communities, ie, inclusive financial policies. One of the inclusive financial programs is Digital Financial Inclusion (DFI), which is digital access to use of formal financial services by underserved populations. Examples of DFI services in Indonesia are internet banking, mobile banking, and emoney.

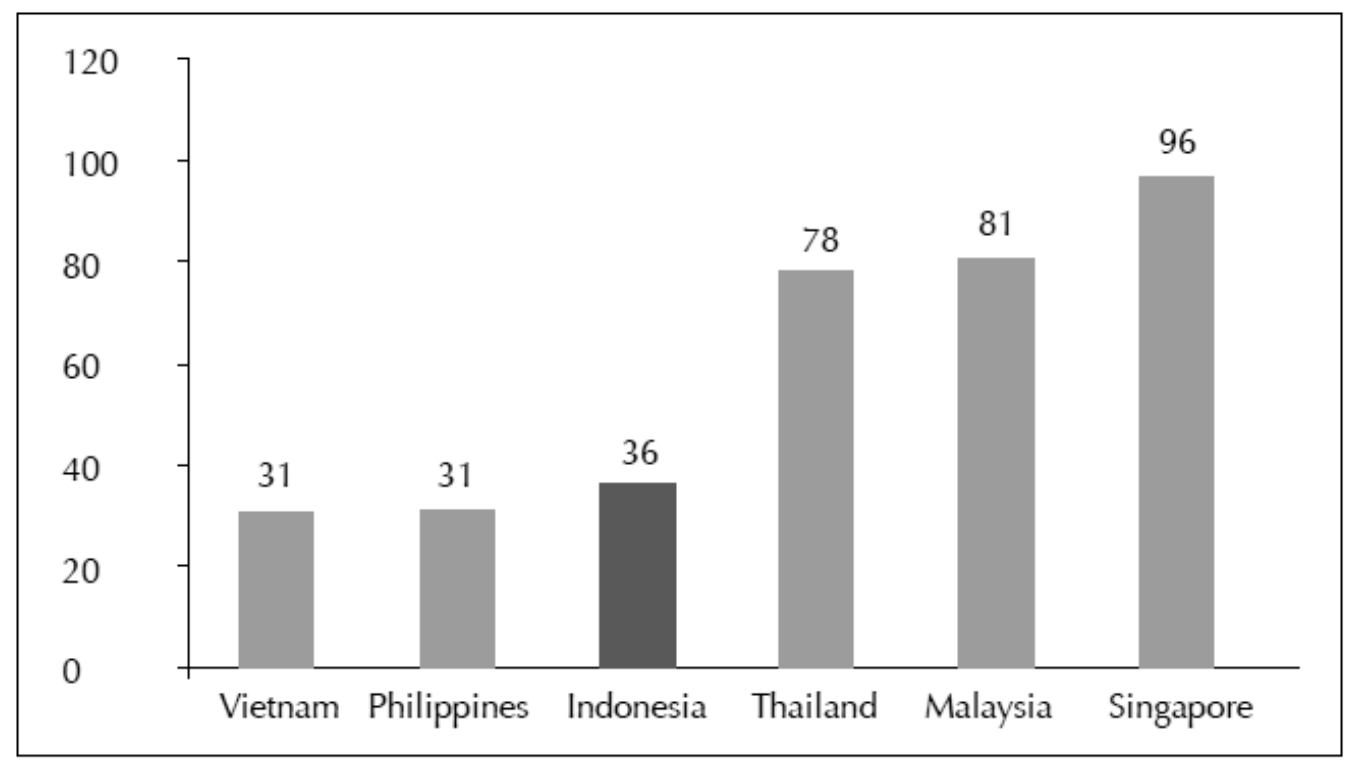

Figure 1: Percentage of population above 15 years who have access to financial institution in some ASEAN countries by 2014

Digitalization is considered appropriate because of its high penetration rate, even among the poor and vulnerable. Some research have suggested that technology has an important role in improving the access of the poor to banks by 
INDEPENDENT JOURNAL OF MANAGEMENT \& PRODUCTION (IJM\&P)

http://www.ijmp.jor.br

v. 9, n. 4, October - December 2018

ISSN: 2236-269X

DOI: 10.14807/ijmp.v9i4.824

providing sustainable financial services (CLAESSENS, 2006). Based on a survey conducted by InterMedia (2015), 79\% of Indonesians have access to mobile phones. Another interesting fact is based on a survey conducted by the Association of Internet Network Providers Indonesia (APJII) which revealed that more than half of Indonesia's population has been connected to the internet now. Based on the results of the APJII (2017) survey, penetration of internet users in Indonesia reached $51.8 \%$ ie $\mathbf{1 3 2 . 7}$ million of the total population $\mathbf{2 5 6 . 2}$ million. There is a fairly rapid increase compared to 2014 , the penetration of internet users of Indonesia was only $34.9 \%$ ie 88.1 million out of total 252.4 million population in 2014 . Therefore, Indonesian is ready for digital financial inlcusion.

Based on Deloitte Consulting (2015), West Java is the province with the highest unbanked population in Indonesia. Based on the research of Ummah (2015), one of the factors that can influence financial inclusion is income distribution. The growing inequality of income (gini index) shows lower levels of financial inclusion. Bogor City's gini index has a big value compared to other cities in West Java in 2015, which is equal to 0.47. Thus, the level of financial inclusion in Bogor City still tends to be lower than others. On the other hand, the digital development in the city of Bogor is quite good. Based on BPS (2017), the percentage of population of Bogor City who have cellular phone (HP) are $69.30 \%$ and $40.49 \%$ of the population has accessed internet. Thus, Bogor City is one of the potential market targets of DFI services.

The success of DFI services are not only determined by the service provider, but also by the acceptance of the users (ORUC; TATARS, 2017). The success of DFI services depend on how consumers receive the service. In other words, an important issue for service providers when implementing DFI is to know what factors affect consumer acceptance in using DFI. Because by knowing these factors then the service providers can encourage the actual interest of customers so willing to use DFI.

One model by Davis (1989) that is often used to describe the level of technology acceptance is the Technology Acceptance Model (TAM). The TAM model offers a powerful and simple explanation for technology acceptance and user behavior (VANKATESH; MORRIS, 2000). In addition, according to Chuttur (2009), MPT is a very popular model and is often used by researchers to explain and estimate the acceptance of a system. Thus, this reasearch used TAM as the model. 
INDEPENDENT JOURNAL OF MANAGEMENT \& PRODUCTION (IJM\&P)

http://www.ijmp.jor.br

v. 9, n. 4, October - December 2018

ISSN: 2236-269X

DOI: 10.14807/ijmp.v9i4.824

The main target of DFI is to improve financial access to all levels of society in Indonesia. Therefore, it is necessary to design a better application system from DFI to be accepted by consumers. The main purpose of this research is to investigate the importance of understanding consumer acceptance of using DFI. The impact of several factors of consumer acceptance through the TAM model ie perceived usefulness, perceived ease of use, perceived credibility, intention to use and actual use of DFI services. The results of this research are expected to provide the information needed to improve the development and acceptance of DFI services.

\section{FRAMEWORK AND LITERATURE REVIEW}

\section{$2.1 \quad$ Research Framework}

This research examines the impact of perceived usefulness, perceived ease of use, and perceived credibility toward the intention to use by customer, reviews the effect of perceived credibility to perceived usefulness and perceived credibility, and also review the effect of intention to use on actual use of DFI services. The research model can be seen in Figure 2.

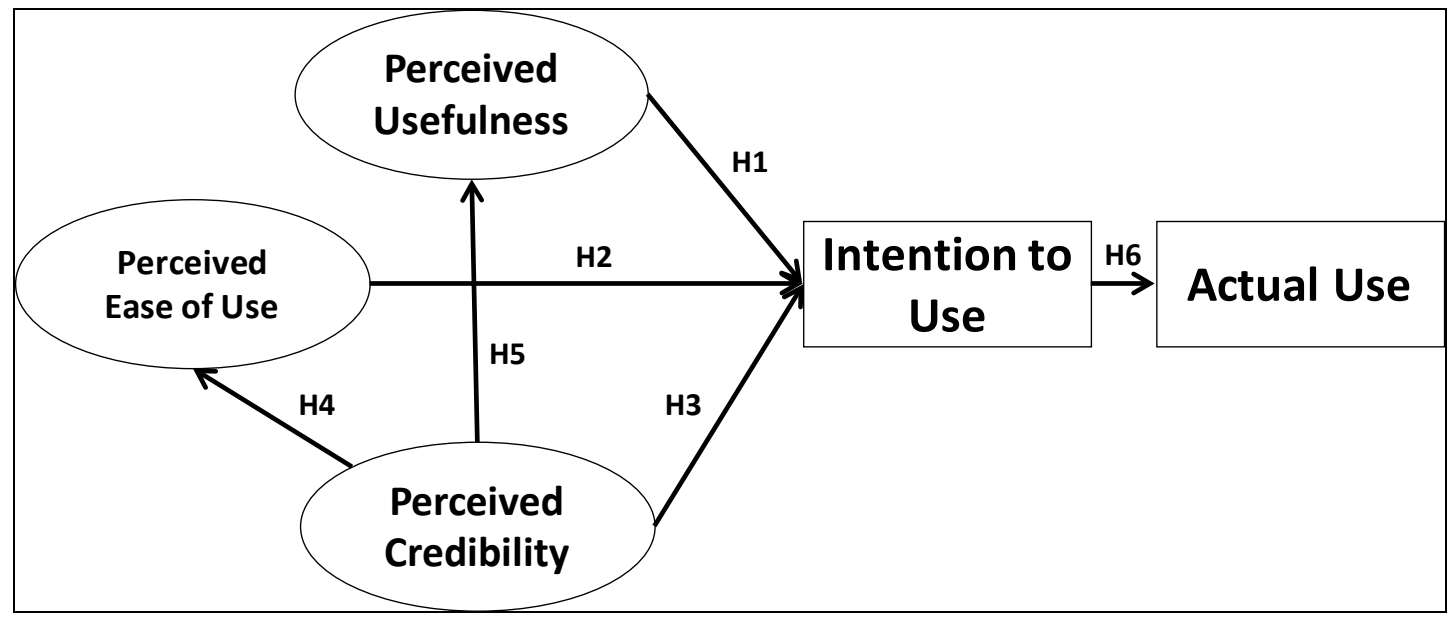

Figure 2: The research model

\section{$2.2 \quad$ Literature Review}

\subsubsection{Perceived Usefulness and Perceived Ease of Use}

Perceived usefulness and perceived ease of use come from TAM (DAVIS, 1989). Perceived usefulness is the extent to which a person believes that using a particular system will improve his performance and the perceived ease of use is defined as the extent to which a person believes that using a particular system will 
INDEPENDENT JOURNAL OF MANAGEMENT \& PRODUCTION (IJM\&P)

http://www.ijmp.jor.br

v. 9, n. 4, October - December 2018

ISSN: 2236-269X

DOI: 10.14807/ijmp.v9i4.824

be free of effort (DAVIS, 1989). Results from a number of studies Eze et al. (2011), Wang et al. (2003), Abadi \& Nematizadeh (2012), Rusu \& Shen (2012), Aderonke \& Charles (2010), Liao \& Wong (2008), Afifah and Widyanesti (2017) and Widjana and Rachmat (2011) show that the perceived usefulness and ease of use that makes customers have a positive attitude to receive and adopt digital financial services. This result is in harmony with Afifah and Widyanesti (2017) research, proving the perceived ease of use usage proved significantly positive toward customer intention to use mobile banking services at one of the banks in Jakarta. By applying it to the context of DFI services, the first two hypotheses are:

$\mathrm{H} 1$ : Perceived usefulness have a positive effect on intention to use DFI services

$\mathrm{H} 2$ : Perceived ease of use positively affects intention to use DFI services

\subsubsection{Perceived Credibility}

Perceived credibility are as far as safe individuals believe that using a system will be free of individual equality and privacy issues (CHUTTUR, 2009). A number of studies (ABADI; NEMATIZADEH, 2012; ADERONKE \& CHARLES, 2010; RAHAYU, 2010; MUNIRUDDEEN, 2007) have tested and confirmed that perceived credibility have a significant influence tp perceived usefulness, perceived ease of use and actual use of ebanking. Therefore, to research the effect of perceived credibility on user acceptance in DFI services, the following hypotheses are:

H3: Perceived credibility have a positive effect on intention to use DFI services

H4: Perceived credibility positively affects the perceived usefulness in using DFI services

H5: Perceived credibility positively affects the perceived ease of use in using DFI services

\subsubsection{Intention to Use and Actual Use of DFI Services}

Davis and Vakentesh (1996) define intention to use as a trend of consumer behavior to use a technology. The use of DFI in question is the actual use of DFI. Davis (1989) defines the actual use of usage as a real and real condition for the use of such a system. The results of Aderonke and Charles (2010) show that the construct of intention to use in technology acceptance model has a positive effect on actual use. The results of Rusu and Shen (2012) also show that the tendency of intention to use to keep using technology has a significant positive effect on the real 
INDEPENDENT JOURNAL OF MANAGEMENT \& PRODUCTION (IJM\&P)

http://www.ijmp.jor.br

v. 9, n. 4, October - December 2018

ISSN: 2236-269X

DOI: 10.14807/ijmp.v9i4.824

condition of technology usage. With an understanding of the following behavioral interests the hypothesis is:

H6: The hypothesis of the influence of behavior interest has a positive effect on the use of DFI in using DFI services

\section{RESEARCH METHODOLOGY}

This research was conducted from January to April 2018. . The object of this research were DFI services which wee well known by consumer, i.e. internet banking, mobile banking, and e-money. Methods of collecting data and information was survey methods with instruments include observation, questionnaires, interviews and literature research. The sampling technique was used purposive sampling (judgmental sampling) which the sample was determined by certain criteria. The criteria of respondents were DFI consumers, living in Bogor City (already settled $\geq 5$ years), and age more than 15 years old. The question type in this questionnaire were multiple choice and scale rating (likert scale). The number of respondents in this research was 134 peopleCriteria of respondents in this research were (1) residents of Bogor City who have settled for at least 5 years, (2) over the age of 15 years and; (3) consumer of DFI services.Processing and data analysis used SmartPLS 3 program.

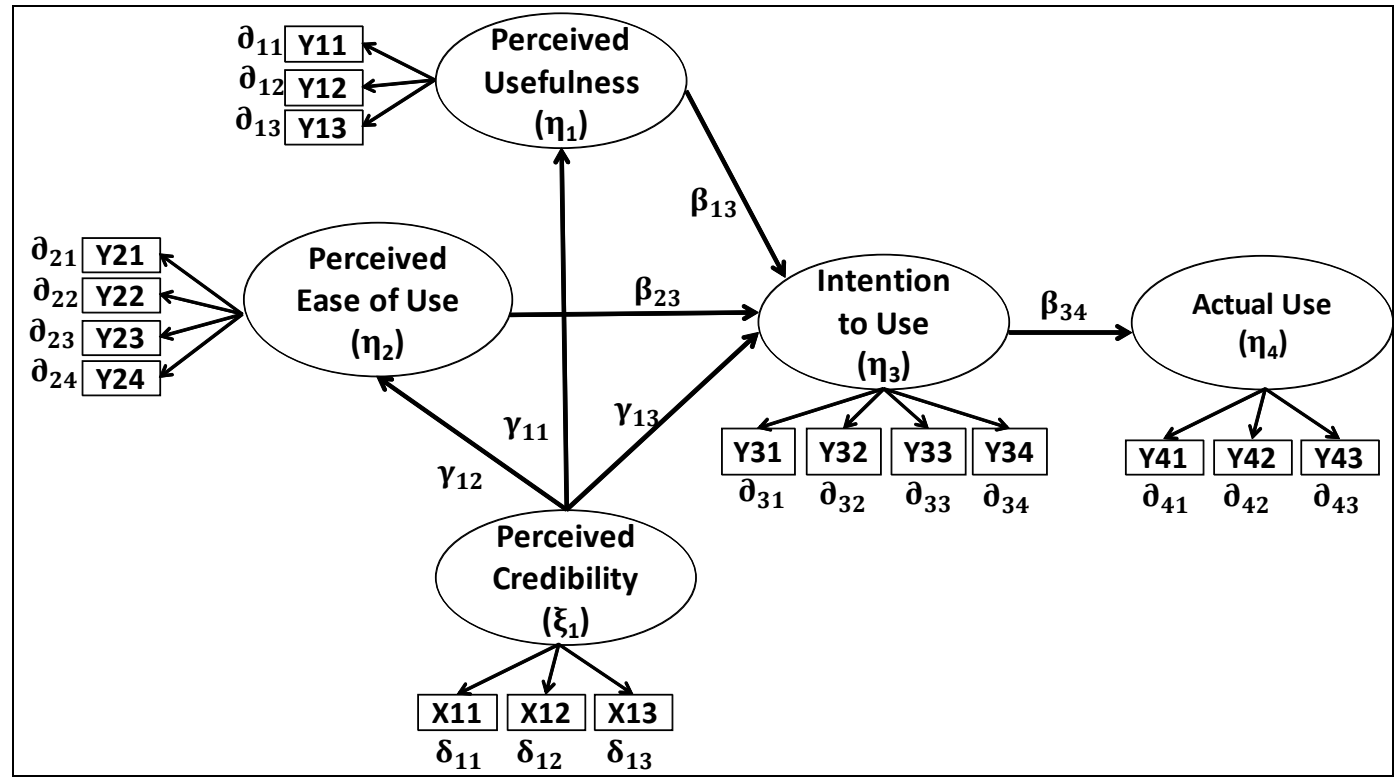

Figure 3: PLS SEM structural model of this research

PLS SEM structural model of this research can be seen in Figure 3. This research illustrates the factors that determine consumer acceptance using DFI 
INDEPENDENT JOURNAL OF MANAGEMENT \& PRODUCTION (IJM\&P)

http://www.ijmp.jor.br

v. 9, n. 4, October - December 2018

ISSN: 2236-269X

DOI: 10.14807/ijmp.v9i4.824

services. Factors analyzed consisted of percived usefulness, perceived ease of use, perceived credibility, intention to use and actual use of DFI services. In this research, perceived usefulness had 3 variable indicators, perceived ease of use had 4 variable indicators, perceived credibility had 3 variable indicators, intention to use had 4 variable indicators and actual use of DFI services had 3 variable indicators.

\section{RESULT AND DISCUSSION}

\subsection{Characteristics of Respondents}

Table 1 shows the profile of the 134 respondents. The respondents in this research are 61\% women and 39\% men. It was not obtained intentionally, because in the acquisition of respondents there is no difference of gender. Age group of respondents in this research is dominated by young age is 20-24 years and 25-29 years. This may be due to the younger age group having better financial independence compared to youth groups (15-19 years) and more early adopters than adult groups ( $\geq 35$ years).

Table 1: Sample profile

\begin{tabular}{clcc}
\hline Variable & \multicolumn{1}{c}{ Description } & Frequncy & Percent (\%) \\
\hline Gender & Male & 52 & $39 \%$ \\
& Female & $\mathbf{8 2}$ & $\mathbf{6 1 \%}$ \\
\hline \multirow{2}{*}{ Age } & $15-19$ years & 5 & $4 \%$ \\
& 20-24 years & 76 & $\mathbf{5 7 \%}$ \\
& 25-29 years & 32 & $24 \%$ \\
& 30-34 years & 4 & $3 \%$ \\
& $\geq 35$ years & 17 & $13 \%$ \\
\hline \multirow{2}{*}{ Education Level } & Primary school & 3 & $2 \%$ \\
& Junior high school & 1 & $1 \%$ \\
& Senior high school & 15 & $11 \%$ \\
& Undergraduate & $\mathbf{1 0 6}$ & $\mathbf{7 9 \%}$ \\
& Postgraduate & 9 & $7 \%$ \\
\hline \multirow{2}{*}{ Pekerjaan } & Non-employed & 4 & $3 \%$ \\
& Entrepreneur & 15 & $11 \%$ \\
& Student & 31 & $23 \%$ \\
& Employee & $\mathbf{6 2}$ & $\mathbf{4 6 \%}$ \\
& Government employee & 4 & $3 \%$ \\
& Etc & 18 & $12 \%$ \\
\hline Income & < Rp 1 million & 17 & $13 \%$ \\
& Rp 1 - 2.5 million & 28 & $21 \%$ \\
& Rp 2.6 - 5 million & 38 & $28 \%$ \\
& $>$ Rp 5 million & $\mathbf{5 1}$ & $\mathbf{3 8 \%}$ \\
\hline
\end{tabular}


INDEPENDENT JOURNAL OF MANAGEMENT \& PRODUCTION (IJM\&P)

http://www.ijmp.jor.br

v. 9, n. 4, October - December 2018

ISSN: 2236-269X

DOI: 10.14807/ijmp.v9i4.824

The respondents at the last level of undergraduate education dominate about 79\%. Respondents with recent senior high school education level followed by a percentage of $11 \%$. And the respondents with the last education finished primary school and Junior High School were only 3\%. This suggests that the level of education affects consumers' adaptability in choosing the financial products and services they use.

Table 1 shows the distribution of respondents by profession dominated by employee groups then students and entrepreneurs. This can be due to the ease and practicality required to transact demanded more in these three professions. Based on income level, respondents with income >Rp 5 million dominate with percentage $38 \%$. While respondents with income $<\mathrm{Rp} 1$ million has the smallest percentage that is only about $13 \%$. This can be due to the greater the income level of a person, the higher the financial literacy (financial literacy), the more sensitive the financial services available.

\subsection{Performance of Indicator Variables}

Factors determining acceptance of the use of DFI services were analyzed using the TAM model consisting of perceived usefulness, perceived ease of use, perceived credibility, intention to use and actual use of DFI. Those factors have its own indicator variables. Perceived credibility and usefulness has 3 indicator variables, whereas perceived ease of use, intention to use, and actual use has 4 indicator variables. The performance of the indicator variables in each factor was indicated through frequency analysis from consumer appraisal result to the statement of indicator variable on each factor in questionnare. Assessment is done by using likert scale 1-5 ( 1 = strongly disagree s.d. 5 = strongly agree). Table 2 shows performance of indicator variables.

Table 2: Descriptive statistics of indicator variables

\begin{tabular}{cccccccc}
\hline Variable & Indicator & $\mathbf{n}$ & Mean & Med & Min & Max & $\begin{array}{c}\text { Standard } \\
\text { Deviation }\end{array}$ \\
\hline \multirow{2}{*}{ Perceived Credibility } & $\mathrm{X} 11$ & 134 & 3.64 & 4 & 1 & 5 & 0.850 \\
(X1) & $\mathrm{X} 12$ & 134 & 3.93 & 4 & 1 & 5 & 0.755 \\
& $\mathrm{X} 13$ & 134 & 4.05 & 4 & 1 & 5 & 0.721 \\
\hline \multirow{2}{*}{ Perceived Usefulness } & $\mathrm{Y} 11$ & 134 & 3.67 & 4 & 1 & 5 & 0.920 \\
(Y1) & $\mathrm{Y} 12$ & 134 & 4.46 & 5 & 1 & 5 & 0.834 \\
& $\mathrm{Y} 13$ & 134 & 4.37 & 5 & 1 & 5 & 0.835 \\
\hline \multirow{2}{*}{ Perceived Ease of } & $\mathrm{Y} 21$ & 134 & 4.28 & 4 & 1 & 5 & 0.878 \\
Use (Y2) & $\mathrm{Y} 22$ & 134 & 4.33 & 5 & 1 & 5 & 0.862 \\
& $\mathrm{Y} 23$ & 134 & 4.20 & 4 & 1 & 5 & 0.937
\end{tabular}


INDEPENDENT JOURNAL OF MANAGEMENT \& PRODUCTION (IJM\&P)

http://www.ijmp.jor.br

v. 9, n. 4, October - December 2018

ISSN: 2236-269X

DOI: 10.14807/ijmp.v9i4.824

\begin{tabular}{cccccccc} 
& $\mathrm{Y} 24$ & 134 & 3.77 & 4 & 1 & 5 & 0.977 \\
\hline \multirow{5}{*}{ Intention to Use (Y3) } & $\mathrm{Y} 31$ & 134 & 3.75 & 4 & 1 & 5 & 1.025 \\
& $\mathrm{Y} 32$ & 134 & 4.08 & 4 & 1 & 5 & 0.811 \\
& $\mathrm{Y} 33$ & 134 & 4.08 & 4 & 1 & 5 & 0.811 \\
& $\mathrm{Y} 34$ & 134 & 4.08 & 4 & 1 & 5 & 0.852 \\
\hline \multirow{3}{*}{ Actual Use (Y4) } & $\mathrm{Y} 41$ & 134 & 3.28 & 4 & 1 & 5 & 1.102 \\
& $\mathrm{Y} 42$ & 134 & 3.92 & 4 & 1 & 5 & 0.763 \\
& $\mathrm{Y} 43$ & 134 & 3.91 & 4 & 1 & 5 & 0.868 \\
\hline
\end{tabular}

\subsection{Evaluation of Model Results}

\subsubsection{Measurement Model Results (Outer Model)}

Evaluation of the measurement model (outer model) is based on three criteria to assess the outer model through testing of convergent validity, discriminant validity, and reliability using SmartPLS 3.2.4 software.

Table 3: The value of loading factor for each indicator variables (convergent validity)

\begin{tabular}{lccc}
\hline Variable & Indicator & $\begin{array}{c}\text { Loading } \\
\text { Factor }\end{array}$ & $\begin{array}{c}\text { Convergent } \\
\text { Validity }\end{array}$ \\
\hline \multirow{2}{*}{ Perceived Credibility (X1) } & X11 & 0.832 & Valid \\
& X12 & 0.931 & Valid \\
& X13 & 0.830 & Valid \\
\hline \multirow{2}{*}{ Perceived Usefulness (Y1) } & Y11 & 0.742 & Valid \\
& Y12 & 0.930 & Valid \\
& Y13 & 0.912 & Valid \\
\hline \multirow{2}{*}{ Perceived Ease of Use (Y2) } & Y21 & 0.902 & Valid \\
& Y22 & 0.869 & Valid \\
& Y23 & 0.926 & Valid \\
Intention to Use (Y3) & Y24 & 0.766 & Valid \\
\hline \multirow{3}{*}{ Actual Use (Y4) } & Y31 & 0.828 & Valid \\
& Y32 & 0.932 & Valid \\
& Y33 & 0.958 & Valid \\
& Y34 & 0.926 & Valid \\
\hline
\end{tabular}

Convergent validity is seen from loading factor value. Indicator variable is reliable (valid) if it has loading factor value above 0.7 . The loading factor value $<0.7$ must be removed from the model and re-estimation of the loading factor values. The result of loading factor in Table 3 shows that all the indicators which was used in this research has value above 0.7 so it is declared reliable/valid.

Because there was no problem with convergent validity then the next tested issue was related to discriminant validity. Discriminant validity can be tested by 
INDEPENDENT JOURNAL OF MANAGEMENT \& PRODUCTION (IJM\&P)

http://www.ijmp.jor.br

v. 9, n. 4, October - December 2018

ISSN: 2236-269X

DOI: 10.14807/ijmp.v9i4.824

comparing the values of the square root of AVE with the correlation value between the variables. From Table 4, it can be seen that the square root value of AVE is greater than the correlation of each construct. So, it can be concluded that there is no problem of discriminant validity.

Table 4: The values of the square root of AVE between the variables (discriminant validity)

\begin{tabular}{lccccc}
\hline & $\begin{array}{c}\text { Actual } \\
\text { Use }\end{array}$ & $\begin{array}{c}\text { Perceived } \\
\text { Usefulness }\end{array}$ & $\begin{array}{c}\text { Perceived } \\
\text { Ease of Use }\end{array}$ & $\begin{array}{l}\text { Perceived } \\
\text { Credibility }\end{array}$ & $\begin{array}{l}\text { Intention } \\
\text { to Use }\end{array}$ \\
\hline Actual Use & 0.856 & & & & \\
\hline Perceived Usefulness & 0.580 & 0.865 & & & \\
\hline Perceived Ease of Use & 0.586 & 0.783 & 0.868 & & \\
\hline Perceived Credibility & 0.622 & 0.561 & 0.637 & 0.866 & \\
\hline Intention to Use & 0.659 & 0.572 & 0.609 & 0.601 & 0.912 \\
\hline
\end{tabular}

The last outer model test after convergent validity and discriminant validity, PLS SEM also performs relaibility test. Reability test measure internal consistency of measuring instrument. Reliability shows the accuracy, consistency and precision of a measuring instrument. Reliability test in the PLS can be done with two methods of Cronbach's alpha value must be greater than 0.7 and the value of composite reliability must be greater than 0.7 . Table 5 shows that all constructs have composite reliability and Cronbach's alpha values above 0.7 . Therefore, there is no reliability/ unidimensionality problem in the established model.

Table 5:The value of Cronbachs Alpha and composite reliability

\begin{tabular}{lcc} 
Variable & $\begin{array}{c}\text { Cronbachs } \\
\text { Alpha }\end{array}$ & $\begin{array}{c}\text { Composite } \\
\text { Reliability }\end{array}$ \\
\hline Perceived Credibility (X1) & 0.831 & 0.899 \\
Perceived Usefulness (Y1) & 0.827 & 0.899 \\
Perceived Ease of Use (Y2) & 0.888 & 0.924 \\
Intention to Use (Y3) & 0.932 & 0.952 \\
Actual Use (Y4) & 0.816 & 0.891 \\
\hline
\end{tabular}

\subsubsection{Evaluation of Structural Model Results (Inner Model)}

Inner model evaluation is tested by three way ie. R-Square, $\mathrm{Q}^{2}$, and GoF value. The R-square value is used to measure the magnitude of the relation of variable (exogenous) to the dependent variable (endogen). Table 6 shows the Rsquare value of perceived usefulness was $31.5 \%$, perceived ease of use was $40.6 \%$, intention to use varible was $46.1 \%$, and actual use variable was $43.4 \%$. This explains the ability of independent variables to explain the dependent variable of perceived 
INDEPENDENT JOURNAL OF MANAGEMENT \& PRODUCTION (IJM\&P)

http://www.ijmp.jor.br

v. 9, n. 4, October - December 2018

ISSN: 2236-269X

DOI: 10.14807/ijmp.v9i4.824

usefulness was $31.5 \%$ and the rest was explained by other independent variables that were not in this research. Furthermore, the ability of independent variables to explain the dependent variable perceived ease of use was $40.6 \%$ and the rest was explained by other independent variables that are not in this research. Then, the ability of independent variable to explain dependent variable of intention to use was $46.1 \%$ and the rest is explained by other independent variable which was not in this research. Meanwhile, the ability of independent variables to explain the dependent variable of actual use was $43.4 \%$ and the rest is explained by other independent variables that are not in this research.

Table 6: The value of R-Square

\begin{tabular}{lc}
\hline \multicolumn{1}{c}{ Variable } & $\mathbf{R}^{\mathbf{2}}$ \\
\hline Perceived Usefulness (Y1) & 0.315 \\
Perceived Ease of Use (Y2) & 0.406 \\
Intention to Use (Y3) & 0.461 \\
Actual Use (Y4) & 0.434 \\
\hline
\end{tabular}

The following for inner model testing can be done by looking at the value of $\mathrm{Q}^{2}$ (predictive relevance) function to validate the model. The value of $\mathrm{Q}^{2}$ of this study was 0.88 (quite large). This suggests that exogenous latent variables were good (as appropriate) as explanatory variables that were able to predict their endogenous variables. Next to measuring the inner model was to find the value of Goodness of Fit (GoF). The GoF value was a single measure to validate the combined performance between the measurement model and the structural model. The GoF value of this study was 0.587 which was large and good. Based on test results of the value of $\mathrm{R}^{2}, \mathrm{Q}^{2}$ and GoF seen that the model formed was robust. So that hypothesis testing can be done.

\subsection{The Relationship between Variable}

If the statistical t-value is more than 1.64 (two-tiled) or 1.96 (one-tiled) and probability value ( $p$-value) less than 0.05 or $5 \%$, so there is significant effecf between variables. In Table 7 can be seen the T-Statistic value of the SEM processed results in each variables. Based on T-statistics which shows relationship between constructs, so: (1) Y2 $\rightarrow Y 3$, (2) X1 $\rightarrow Y 1$, (3) X1 $\rightarrow Y 2$, (4) X1 $\rightarrow Y 3$, and (5) Y3 $\rightarrow Y 4$ because it has a $T$ value of statictics $>1.96$ and a value of $P$ value $<0.05$. While the relationship between $\mathrm{Y} 1 \rightarrow \mathrm{Y} 3$ proved to be insignificant because it has a static $\mathrm{T}$ value of $1.590(<1.96)$ and the value of $P$ value of $0.112(>0.05)$. So, perceived 
INDEPENDENT JOURNAL OF MANAGEMENT \& PRODUCTION (IJM\&P)

http://www.ijmp.jor.br

v. 9, n. 4, October - December 2018

ISSN: 2236-269X

DOI: 10.14807/ijmp.v9i4.824

usefulness has no significant effect to intention to use. But, perceived use of ease \& credibility has positive and significant effect to intention to use. Perceived credibility also has significant and positive effect to perceived usedulness and ease of use. And intention to use has significant and positif effect to actual use.

Table 7: The result of PLS SEM bootstraping

\begin{tabular}{cccccccc}
\hline & & $\begin{array}{c}\text { Original } \\
\text { Sample } \\
\text { (0) }\end{array}$ & $\begin{array}{c}\text { Sample } \\
\text { Mean } \\
\text { (M) }\end{array}$ & $\begin{array}{c}\text { Standard } \\
\text { Deviation } \\
\text { (STDEV) }\end{array}$ & $\begin{array}{c}\text { T Statistics } \\
\text { (|O/STDEV |) }\end{array}$ & $\begin{array}{c}\text { P } \\
\text { Values }\end{array}$ & Sig. \\
\hline H1 & Y1 --> Y3 & 0.192 & 0.194 & 0.121 & 1.590 & 0.103 & Tidak Sig \\
H2 & Y2 --> Y3 & 0.243 & 0.237 & 0.094 & 2.581 & 0.007 & Sig \\
H3 & X1 --> Y3 & 0.338 & 0.354 & 0.077 & 4.377 & 0.000 & Sig \\
H4 & X1 --> Y1 & 0.561 & 0.556 & 0.090 & 6.203 & 0.000 & Sig \\
H5 & X1 --> Y2 & 0.637 & 0.630 & 0.094 & 6.769 & 0.000 & Sig \\
H6 & Y3 --> Y4 & 0.659 & 0.662 & 0.062 & 10.694 & 0.000 & Sig \\
\hline \multicolumn{7}{l}{ Note: X1 (Perceived Credibility), Y1 (Perceived Usefulness), Y2 (Perceived Ease of Use), } \\
\multicolumn{7}{c}{ Y3 (Intention to Use), Y4 (Actual Use), Sig (Significant) }
\end{tabular}

The results of this research as shown in Table 7 indicate that there was no significant effect of the perceived usefulness to intention to use. In other words, consumer confidence about the usefulness of DFI services can not affect their intention to use the service. The results of this research in line with the results of Hosein (2009) which shows that the perception of the use of ebanking has no significant effect in determining consumer behavior interest in using it in the Midwest. This may be because the respondent has not considered that usability of DFI is important because it can be obtained from various other services.

The results of this research as shown in Table 7 indicate that there was significant effect of the perceived ease of value to intention to use. The results of this research in line with the results of Afifah and Widyanesti (2017) which was describing the acceptance of mobile banking in Jakarta using the MPT approach also indicates that the perceived of ease of use has a significant positive effect to intention to use mobile banking services in Jakarta. Each increase of 1 unit from the value of the perceived ease of use (Y2) will increase 0.243 unit from the value of intention to use (Y3). In other words, consumer trust that DFI services are easy to use can affect their intention to use. Consumers think that using DFI services is a good and profitable idea.

The results of this research as shown in Table 7 indicate that there was positive and significant effect of the perceived credibility to intention to use. The 
INDEPENDENT JOURNAL OF MANAGEMENT \& PRODUCTION (IJM\&P)

http://www.ijmp.jor.br

v. 9, n. 4, October - December 2018

ISSN: 2236-269X

DOI: 10.14807/ijmp.v9i4.824

results of this research in line with the results of Rahayu (2010) and Jalal et al. (2011) which show that the perceived credibility has a positive and significant effect on the acceptance of ebanking. Each increase of 1 unit from the value of the perceived credibility (Y2) will increase 0.338 unit from the value of intention to use (Y3). So, consumer confidence about the credibility of the service provider may affect intention to use. If consumers feel confident about the service provider's credibility then they will like to use DFI and think that using it is a good idea.

The results show that perceived credibility has significant and positive effect to perceived usedulness and ease of use. The results of this research in line with the results of Aderonke and Charles (2010) and Rahayu (2010). Aderonke and Charles (2010) show that perceived credibility has significant and positive effect to perceived usedulness and ease of use of ebanking in Negeria. And Rahayu (2010) also show that perceived credibility has significant and positive effect to perceived usedulness and ease of use of ebanking in Indonesia. Each increase of 1 unit from the value of the perceived credibility (Y2) will increase 0.637 unit from the value of perceived usefulness (Y1) and 0.561 unit from the value of perceived ease of use (Y2). So, the consumer's trust in the credibility of the service provider can affect his belief in the usefulness and ease of use of the services. The more consumers feel secure and trust the DFI service provider, the consumer will like to use it and think that using the DFI service is a good and profitable idea as it facilitates financial transactions.

The last relation in this research was between intention to use and actual use of DFI services. From the results in Table 7, intention to use has positive and significant effect to actual use of DFI services. Every increase of 1 unit from the value of the perceived credibility (Y2) will increase 0.659 unit from the value of perceived usefulness (Y1). So, changes in intention to use DFI services will affect the actual usage of the DFI services. The more consumers feel happy /satisfied (positive) of the using DFI services, so it will increase the actual use of the DFI service. Conversely, if the DFI services can not make consumers happy/satisfied then consumers will reduce/stop using the DFI.

There are several variables that are suspected to be mediator in this research that were perceived usefulness and ease of use. Based on the results of statistical analysis using PLS SEM which can be seen in Table 8, shows that the perceived usefulness (Y1) was not a mediating variable between perceived credibility (X1) and 
INDEPENDENT JOURNAL OF MANAGEMENT \& PRODUCTION (IJM\&P)

http://www.ijmp.jor.br

v. 9, n. 4, October - December 2018

ISSN: 2236-269X

DOI: 10.14807/ijmp.v9i4.824

intention to use $(Y 3)$ because it has the value of T Statistics $1.668(<1.96)$ and $P$ values 0.096 (> 0.05). While the perceived credibility $(X 1)$ has a positive and significant effect on intention to use (Y3) through perceived ease of use (Y2) because it has the value of T Statistics $2.472(>1.96)$ and $P$ values $0.014(<0.05)$. Based on Table 7, perceived credibility (X1) has a significant relationship to behavioral interest $(\mathrm{Y} 3)$. So, it can be concluded that this mediation is quasimediating. This means that independent variables (perceived credibility) can directly influence the dependent variable (intention to use) without going through/involving the mediator variable (perceived ease of use).

Table 8: Total Indirect effects

\begin{tabular}{|c|c|c|c|c|c|}
\hline & $\begin{array}{c}\text { Original } \\
\text { Sample } \\
(0)\end{array}$ & $\begin{array}{c}\text { Sample } \\
\text { Mean } \\
(\mathrm{M})\end{array}$ & $\begin{array}{l}\text { Standard } \\
\text { Deviation } \\
\text { (STDEV) }\end{array}$ & $\begin{array}{l}\text { T Statistics } \\
\text { (|O/STDEV|) }\end{array}$ & $\begin{array}{c}P \\
\text { Values }\end{array}$ \\
\hline $\mathrm{X} 1$-> Y1> Y3 & 0.108 & 0.109 & 0.065 & 1.668 & 0.096 \\
\hline$X 1->Y 2->Y 3$ & 0.155 & 0.148 & 0.063 & 2.472 & 0.014 \\
\hline
\end{tabular}

\section{CONCLUSION}

The aims of this research examined the factors that influence the acceptance of DFI services in Bogor, Indonesia. Based on the results of this research, perceived usefulness have no significant effect $(p>0.05)$ to intention to use DFI services. While perceived ease of use and credibility significantly positive $(p<0.05)$ affect intention to use DFI services. The results of this research also proves that there were positive and significant effect from perceived credibility to perceived usefulness and ease of use at 5\% significance level. 'Intention to use' also proved that have a significant positive effect $(p<0.05)$ to the actual use of DFI services. The perceived ease of use in this research was a pseudo-mediator variable between perceived credibility and intetion to use DFI services. So, we recommend that DFI service providers pay more attention to perceived credibility aspects that most influence consumer intention to use and not to focus too much on perceived usefulness of DFI services because it did not have significant effect to consumer intention to use.

\section{REFERENCES}

ABADI, H.R.; NEMATIZADEH, F. (2012) An empirical investigation of th level of user's acceptance of e-banking among some customers of bank in Iran. Intetnational Journal of Academic Research in Business and Social Sciences, v. 2 , n. 6 , p. $418-430$. 
INDEPENDENT JOURNAL OF MANAGEMENT \& PRODUCTION (IJM\&P)

http://www.ijmp.jor.br

v. 9, n. 4, October - December 2018

ISSN: 2236-269X

DOI: 10.14807/ijmp.v9i4.824

ADERONKE,A.; CHARLES. (2010) An Empirical Investigation of the Level of Users' Acceptance of E-Banking in Nigeria. Journal Internet Banking and Commerce, v. 15 , n. 1, p. 102-145.

AFIFAH, F.; WIDYANESTI, S. (2017) Analysis of Mobile Banking Usage by Adopting Technology Acceptance Model (TAM). E-Proceeding of Management, v. 4, n. 1, p. 46-52.

AFIFAH, F; WIDYANESTI, S. (2017) Analisis Penggunaan Mobile Banking dengan Mengadopsi Technology Acceptance Model (TAM). E-Proceeding of Management, v. 4, n. 1, p. 46-52.

ASSOCIATION OF INDONESIAN INTERNET SERVICE PROVIDERS. (2017)

Penetration \& Behavior of Indonesian Internet Users. Available:

https://apjii.or.id/survei2017/download/nqVxdUK1fOJZ25ucmDwNH43WChrg9v.

Access: November 19 ${ }^{\text {th }}, 2017$.

Central Bureau of Statistics. (2017) City of Bogor in Figures 2017. Available: https://bogorkota.bps.go.id/publication/2017/08/11/f02aa6ec54d4eacd9b22dfda/kotabogor-dalam-angka-2017.html. Access: January 13 ${ }^{\text {th }}, 2018$.

CHUTTUR, M. (2009) Overview of the Technology Acceptance Model: Origins, Developments and Future Directions. Sprouts: Working Papers on Information Systems, v. 9, n. 37, p. 1-21.

CLAESSENS, S. (2006) Access to financial services: a review of the issues and public policy objectives. The World Bank Research Observer, v. 20, p. 207-240.

DAVIS, F.D. (1989) Perceived usefulness, perceived ease of use, and user acceptance of information technology. Management Information Systems Quarterly, v. 13, n. 3, p. 318-339.

DELOITTE CONSULTING. (2015) The Future is Now Digital Financial Services in Indonesia. Jakarta: Deloitte Indonesia.

EZE, U. C.; et al. (2011) Factors affecting internet banking adoption among young adults. International Journal of Social Science and Humanity, v. 5, n. 6, p. 377381.

HOSEIN. (2009) Internet banking: an empirical research of adoption rates among midwest community banks. Journal of Business and Economics Review, v. 7, n.11, p. 51-72.

INTERMEDIA. (2015) Indonesia FII Tracker Surveys Wave. Washington: Bill \& Melinda Gates Foundation.

JALAL, A.; MARZOOQ, J.; NABI, H.A. (2011) Evaluating the impacts of online banking factors on motivating the proces of e-banking. Journal Management Studies, v. 1, n. 1, p. 32-42.

LIAO, Z; WONG, W. K. (2008) The determinants of customer interactions with internet-enabled e-banking services. Journal of Operational Research Society, v. 59 , n. 9, p. 1201-1210.

MUNIRUDDEEN, L. (2007) An Examination of Individual's Perceived Security and Privacy of the Internet in Malaysia and the Influence of This on Their Intention to Use E-Commerce: Using An Extension of the Technology Acceptance Model. Journal Internet Banking and Commerce, v. 12, n. 3, p. 14-27. 
ORUC, O.E.; TATAR, C. (2017) An investigation of factors that affect internet banking usage based on structural equation modeling. Computer in Human Behavior, v. 66, p. 232-235.

RAHAYU. (2010) Technology Acceptance Model to analyse the approval of ebanking services. Jakarta: Institut Keuangan Perbankan dan Informatika Asia Perbanas.

RUSU, R. F; SHEN, K. N. (2012) An empirical research on e-banking acceptance in the United Arab Emirates (UAE). Journal of Economics and Behavioral Studies, v. 1, n. 1, p. 1-9.

UMMAH. (2015) Analysis of financial inclusion and equitable income in Indonesia. Bogor: Master Graduate, Bogor Agricultural University.

VANKATESH AND MORRIS. (2000) Age Differences in Technology Adoption Decisions: Implications for a Changing Workforce. Journal of Personalty and Social Psychology, v. 53, n. 3, p. 375-403.

WANG, Y.S.; et al. (2003) Determinants of user acceptance of internet banking: an empirical research. International Journal of Service Industry Management, v. 14, n. 5, p. 501-519.

WIDJANA, M. A; RACHMAT, B. (2011) Factors determining acceptance level of internet banking implementation. Journal of Economics Business and Accountanct Ventura, v. 14, n. 2, p. 161-174. 